In het geval dat het onderzoek ter terechtzitting is aangevangen en vervolgens voor onbepaalde tijd wordt geschorst, terwijl het openbaar ministerie, nadat de oorzaak van de schorsing is vervallen, nalaat het onderzoek ter terechtzitting te doen hervatten door, kort gezegd, het opnieuw aanbrengen van de zaak op een nadere terechtzitting, vormt dat nalaten gelet op wat onder 4.4 is overwogen - geen grond warop een verklaring als bedoeld in art. $36 \mathrm{~Sv}$ kan worden gegeven dat de zaak is geëindigd. Geen rechtsregel staat er echter aan in de weg dat de verdachte zich in dat geval wendt tot de voorzitter van het gerecht waar de zaak dient, met het verzoek de dag van de nadere terechtzitting te bepalen.

\subsection{1}

Overschrijding van de redelijke termijn kan aanleiding geven tot strafvermindering, maar leidt niet tot de niet-ontvankelijkverklaring van het openbaar ministerie in de strafvervolging, ook niet in uitzonderlijke gevallen (vgl. HR 17 juni 2008, ECLI:NL:HR:2008:BD2578, rov. 3.21-3.23). Dat staat - gelet op het rechtsgevolg dat art. 255, eerste lid, Sv verbindt aan de beschikking dat de zaak is geëindigd, inhoudende dat de verdachte alleen bij het bekend worden van nieuwe bezwaren opnieuw in rechte kan worden betrokken ter zake van hetzelfde feit - tevens eraan in de weg dat de rechter op de voet van art. $36 \mathrm{~Sv}$ verklaart dat de zaak is geëindigd op de grond dat het recht op berechting binnen een redelijke termijn als bedoeld in art. 6, eerste lid, EVRM is geschonden. Dat is niet anders indien aan een verzoek als bedoeld in art. $36 \mathrm{~Sv}$ (mede) ten grondslag is gelegd dat de overschrijding van de redelijke termijn tevens een inbreuk op andere verdedigingsrechten tot gevolg heeft, bijvoorbeeld waar het de mogelijkheid betreft van het bieden van een behoorlijke en effectieve gelegenheid tot ondervraging. Het is aan de zittingsrechter en niet aan de rechter die oordeelt over het verzoek als bedoeld in art. $36 \mathrm{~Sv}$, te bepalen of van zo'n inbreuk sprake is en zo ja, of dat in de concrete omstandigheden van het geval ook betekent dat zich een schending van art. 6 EVRM voordoet waaraan bij de berechting van de zaak gevolgen dienen te worden verbonden (vgl. HR 13 september 2016, ECLI:NL:HR:2016:2059).

\subsection{2}

Grond voor het geven van een verklaring dat de zaak is geëindigd kan de rechter onder meer wel vinden in de omstandigheid dat niet of nauwelijks (meer) activiteiten worden verricht in het strafrechtelijk onderzoek tegen de verdachte en het daarnaast redelijkerwijs niet valt te verwachten dat het openbaar ministerie tegen de verdachte strafvervolging zal instellen of voortzetten, in het bijzonder door jegens de verdachte een strafbeschikking uit te vaardigen of hem te dagvaarden, zonder dat het openbaar ministerie daaromtrent zelf al duidelijkheid heeft verschaft aan de verdachte in de vorm van een (sepot)beslissing als bedoeld in art. 167 of $242 \mathrm{~Sv}$ dan wel anderszins. Mede vanwege het door art. 255, eerste lid, Sv aan de verklaring dat de zaak is geëindigd verbonden rechtsgevolg, betreft het hier een tot terughoudendheid nopende maatstaf. Bij de toepassing daarvan kan de rechter in voorkomende gevallen onder meer in aanmerking nemen dat het openbaar ministerie nalatig is geweest gevolg te geven aan een door de rechter-commissaris op grond van art. 180, derde lid, Sv gestelde termijn tot beëindiging van het opsporingsonderzoek, dan wel dat, niettegenstaande een aanhouding op de beslissing van het verzoek als bedoeld in art. 36, tweede lid, Sv, geen nadere activiteiten van het openbaar ministerie met betrekking tot het tegen de verdachte gerichte onderzoek of de strafvervolging van de verdachte zijn gebleken.'

\section{NTS 2020/18}

HR 1 oktober 2019, 18/00057, ECLI:NL:HR:

2019:1481

\begin{abstract}
Medeplegen voorbereidingshandelingen hennepteelt door in bedrijfspand armaturen, assimilatielampen, transformatoren en koolstoffilters voorhanden te hebben, art. 11a Opiummet. Voorhanden hebben stoffen en voormerpen hennepkmekerij bij ontmanteling daarvan nog 'bestemd tot' beroepsmatige en / of grootschalige hennepteelt?
\end{abstract}

\section{Aantekening redactie}

In artikel 11a Opiumwet is - kort gezegd - strafbaar gesteld het verrichten van handelingen ter voorbereiding of vergemakkelijking van illegale hennepteelt ('growshopverbod'). ${ }^{14}$ Ondernemingen zoals growshops hebben zich toegelegd op handelingen ter voorbereiding of vergemakkelijking van illegale hennepteelt. Bedrijfsactiviteiten die zich toeleggen op deze handelingen zijn sinds 2015 strafbaar. Voor strafbaarheid is vereist dat de aangetroffen stoffen en voorwerpen zijn 'bestemd tot' beroepsmatige en/of grootschalige hennepteelt. In de onderhavige zaak warden weliswaar armaturen, assimilatielampen, transformatoren en koolstoffilters (overdui-

'Hij die stoffen of voorwerpen bereidt, bewerkt, verwerkt, te koop aanbiedt, verkoopt, aflevert, verstrekt, vervoert, vervaardigt of voorhanden heeft dan wel vervoermiddelen, ruimten, gelden of andere betaalmiddelen voorhanden heeft of gegevens voorhanden heeft, waarvan hij weet of ernstige reden heeft om te vermoeden dat zij bestemd zijn tot het plegen van een van de in artikel 11, derde en vijfde lid, strafbaar gestelde feiten, wordt gestraft met gevangenisstraf van ten hoogste drie jaar of geldboete van de vijfde categorie.' 
delijk bedoeld om hennep te telen) aangetroffen, maar die stoffen en voorwerpen werden aangetroffen in een pand waarin op dat moment een eerdere hennepkwekerij werd opgeruimd. De verdachten waren het pand daarom ook aan het schoonmaken. Hoe toekomstgericht dient het bestemmingsvereiste te zijn? Het hof oordeelde dat was voldaan aan het bestemmingsvereiste en legde een werkstraf op. Het hof was van oordeel dat reeds uit het aantreffen van de grote hoeveelheden goederen (o.m. 56 armaturen, 58 assimilatielampen, 59 transformatoren en 8 koolstoffilters) volgt dat de goederen waren bestemd voor grootschalige hennepkweek. Dit bewijst echter niet meer dan dat de goederen ooit bestemd waren voor die opgeruimde hennepkwekerij, maar niet dat ze wederom gebruikt zouden worden voor een nieuwe teelt. Uiteraard werd er in het cassatiemiddel op gewezen dat de hennepkwekerij was opgedoekt en werd opgeruimd. De Hoge Raad maakt (o.m. door te verwijzen naar op de wetsgeschiedenis gebaseerde eerdere rechtspraak ${ }^{15}$ ) echter duidelijk dat 'bestemming' ziet op de toekomst, niet op het verleden, hetgeen betekent dat voor een bewezenverklaring vereist is dat die bestemming ten tijde van het tenlastegelegde nog actueel is en dat de verdachte daarvan weet heeft:

'Voor een bewezenverklaring van de bestemming als bedoeld in art. 11a Opiumwet is vereist dat de gedragingen strekken tot voorbereiding of vergemakkelijking van hennepteelt, waarbij het uiteindelijke doel ten behoeve waarvan de handeling wordt verricht van belang is (vgl. HR 13 maart 2018, ECLI:NL:HR: 2018:328). Gelet daarop heeft het Hof de bewezenverklaring ontoereikend gemotiveerd, nu uit de bewijsvoering onder meer blijkt dat op de in de bewezenverklaring vermelde pleegdatum, 6 april 2016, in het bedrijfspand, waar de verdachte aanwezig was en de in de bewezenverklaring genoemde stoffen en voorwerpen zich bevonden, een hennepkwekerij werd opgeruimd en het pand werd schoongemaakt, terwijl het Hof geen nadere vaststellingen heeft gedaan met betrekking tot het uiteindelijke doel van het op de pleegdatum voorhanden hebben van die stoffen en voorwerpen.'

15. HR 13 maart 2018, ECLI:NL:HR:2018:328. ('Blijkens de hiervoor weergegeven wetsgeschiedenis is voor een bewezenverklaring van de bestemming als bedoeld in art. 11a Opiumwet vereist dat de gedragingen strekken tot voorbereiding of vergemakkelijking van hennepteelt, waarbij het uiteindelijke doel ten behoeve waarvan de handeling wordt verricht van belang is. Gelet daarop heeft het Hof de bewezenverklaring ontoereikend gemotiveerd, nu het voor het bewijs onder meer heeft gebezigd de verklaring van de verdachte voor zover die inhoudt: "De goederen zijn aangetroffen in de oude ruimte, waar vroeger een hennepplantage is aangetroffen. Ik heb die spullen gewoon niet opgeruimd. Ik heb de kelder waarin de goederen zijn aangetroffen dichtgemaakt. Ik heb het luik nog wel eens geopend, maar makkte dat vervolgens dicht. Ik vind het goed zo dacht ik."')
NTS 2020/19

HR 1 oktober 2019, 18/01426, ECLI:NL:HR:

2019:1476

Jeugdzaak. Diefstal met gemeld (art. $312.1 \mathrm{Sr}$ ) en mishandeling (art. 300.1 Sr). Benoeming deskundige. Kan een niet als deskundige in de zin van art. $51 i .1 \mathrm{~Sv}$ benoemd persoon door rechter ttz. als 'deskundige' morden gehoord?

\section{Aantekening redactie}

Het middel in deze jeugdzaak klaagde dat het hof drie personen (waaronder mensen van de Jeugdbescherming en de Raad voor de Kinderbescherming) ter zitting als deskundige heeft gehoord zonder dat deze personen voorafgaand aan het horen als deskundige zijn benoemd met een opdracht tot het geven van informatie of het doen van onderzoek op een terrein waarvan zij specifieke of bijzondere kennis bezitten, als bedoeld in artikel 5li lid 1 Sv. Kan dat? De Hoge Raad oordeelt dat de opvatting dat een persoon uitsluitend als deskundige ter terechtzitting door de rechter kan worden gehoord indien deze persoon voorafgaand aan dat verhoor overeenkomstig artikel 5li lid $1 \mathrm{~Sv}$ op de in de wet bepaalde wijze - als deskundige is benoemd, onjuist is. De rechter is op grond van artikel $299 \mathrm{~Sv}$ in verbinding met artikel 287 lid 2 en $3 \mathrm{~Sv}$ en artikel 315 lid $1 \mathrm{~Sv}$ bevoegd tot het doen oproepen en het horen als deskundige van een persoon op een terrein waarvan hij specifieke of bijzondere kennis bezit, ook als deze niet tevoren als deskundige is benoemd met een opdracht tot het geven van informatie of het doen van onderzoek. Dat neemt niet weg dat de rechter kan beslissen dat voorafgaand aan het horen ter terechtzitting benoeming tot deskundige dient plaats te vinden, bijvoorbeeld omdat het is aangewezen dat voorafgaand aan dat verhoor door de betreffende persoon een schriftelijk verslag over een voor de strafzaak relevant vraagpunt of te verrichten onderzoek wordt uitgebracht. Het is vervolgens aan de rechter om bij de beantwoording van de vragen van artikel 348 en $350 \mathrm{~Sv}$ te beoordelen welke betekenis toekomt aan de ter terechtzitting afgelegde verklaring, waarbij onder meer de deskundigheid van de betreffende persoon met betrekking tot de an zijn oordeel onderworpen vragen van belang kan zijn. ${ }^{16}$

Niet elke persoon die als deskundige op de terechtzitting wordt gehoord is een forensisch deskundige als bedoeld in artikel 51i Sv e.v. en de bepalingen over de

16. Vgl. HR 12 juli 2011, ECLI:NL:HR:2011:BP8821. 